BULLETIN Bulletin hispanique

HISPANIQUE Université Michel de Montaigne Bordeaux

$112-2 \mid 2010$

Varia

\title{
Entre la apropiación y el homenaje
}

una canción de Tejada Páez y una oda de Medrano

\section{J. Ignacio Díez Fernández}

\section{(2) OpenEdition}

Journals

Edición electrónica

URL: http://journals.openedition.org/bulletinhispanique/1221

DOI: 10.4000/bulletinhispanique.1221

ISSN: 1775-3821

Editor

Presses universitaires de Bordeaux

Edición impresa

Fecha de publicación: 31 diciembre 2010

Paginación: 553-585

ISBN: 978-2-86781-709-0

ISSN: 0007-4640

Referencia electrónica

J. Ignacio Díez Fernández, « Entre la apropiación y el homenaje », Bulletin hispanique [En línea],

112-2 | 2010, Publicado el 05 enero 2014, consultado el 05 mayo 2019. URL : http://

journals.openedition.org/bulletinhispanique/1221 ; DOI : 10.4000/bulletinhispanique.1221 


\title{
Entre la apropiación y el homenaje: una canción de Tejada Páez y una oda de Medrano
}

\author{
J. Ignacio Díez Fernández \\ Universidad Complutense
}

Medrano reprend dans son ode à Philippe III différents vers d'une chanson de Tejada Páez, publiée dans les Flores de poetas ilustres. Il convient d'explorer la mince frontière entre imitation et plagiat pour déterminer la fonction de ces emprunts dans deux textes qui, au delà de l'appropriation ou de l'hommage, sont aussi différents dans leur genre, leur contexte et leurs intentions.

Medrano incorpora en su oda a Felipe III varios versos de una canción de Tejada Páez, publicada en las Flores de poetas ilustres. Es necesario explorar la delgada frontera entre la imitación y el plagio para determinar la función de esos préstamos en dos textos que, por encima de la apropiación o el homenaje, se muestran tan distintos en su género, en su contexto y en su intención.

In his ode to Philippe III, Medrano takes up again several verses from one of Tejada Paez's songs, published in Flores de poetas ilustres. Exploring the thin border between imitatio and plagiarism is necessary in order to determine the function of these borrowings in two texts that, beyond appropriation or homage, are as different in genre, context and intention.

Mots-clés : Appropriation - Hommage - Plagiat - Medrano - Tejada Páez.

Bulletin Hispanique, Tome 112, nº 2 - décembre 2010 - p. 553 à 585. 
$\mathrm{P}$ robablemente la oda de Medrano que menos gustó a Dámaso Alonso se diferencia de las demás del conocido poeta sevillano por varios motivos, pues no es horaciana, utiliza una métrica más propia de una canción, es una composición de circunstancias (un panegírico de Felipe III), y presenta importantes coincidencias con una canción de Tejada Páez copiada en diversos manuscritos (en la Poética silva, entre otros) y publicada en las Flores de poetas ilustres de Pedro de Espinosa ${ }^{1}$. Por todas estas razones y por alguna otra (como el «inexplicable» elogio de Felipe III, frecuente en la época ${ }^{2}$ ) Alonso no consideró necesario detenerse en un análisis detallado de la oda-canción. Este trabajo pretende cubrir ese vacío en la medida de lo posible y comparar los dos textos, el de Tejada y el de Medrano, no tanto para determinar qué versos y motivos han pasado de uno a otro como para valorar la función de esos "préstamos» y establecer las claras diferencias que, por encima de la apropiación o el homenaje, separan la canción y la oda.

Las Flores de poetas ilustres, recopiladas por Pedro de Espinosa, publican,

1. «Es la de más longitud de Medrano, y la de estrofa más larga, y en ella está evidente la huella de las obras patrióticas de Herrera, y de piezas como la de Góngora A la Armada que fue a Inglaterra (1588) [...] Todo, en el fondo, frío, frío. Herrera es mucho más alentado en sus odas patrióticas [...] Hay dos versos en la oda de Medrano [vv. 71-72] que definen bien esta oda: en toda ella rimbomba de lo lindo el parche hispano. ¡Dios mío!, ¿pero es Medrano éste? [...] No, no es éste nuestro Medrano. Es quizá su negación. Todo lo que en él es contención, delicadeza, contención sentenciosa, es aquí desenfreno, hipérbole, imagen desaforada. Nada más extrańo (para el lector de las odas horacianas de Medrano) que la estructura misma de esta oda salmanticense: ésta es oda bárbara, como todas las originales escritas en Italia o en España; es decir tiene un desarrollo discursivo, lógico, exterior, rectilíneo», Dámaso Alonso, Vida y obra de Medrano, I, Madrid, CSIC, 1948, pp. 231 y 232. "[...] demuestra en sumo grado la frialdad que suele presentarse en las poesías de encargo de Medrano [...] La oda de Medrano no merece un análisis detenido», Dámaso Alonso y Stephen Reckert, Vida y obra de Medrano, II, Edición crítica, Madrid, CSIC, 1958, pp. 66 y 67.

2. «Las imágenes podrían llegar a grandeza si lo representado hubiera podido comunicar al poeta entusiasmo sincero. Pero ¿quién se imagina, por lo menos hoy, a Felipe III disfrazado de generoso león?», D. Alonso, op. cit., p. 232. Quizá no es muy acertado juzgar la "grandeza» de una imagen por su correlato, así como tampoco parece justo proyectar sobre el pasado lo que sólo el futuro permite conocer. Y si resulta difícil imaginar a un literato que viviera en España en el s. XVII elaborando un duro juicio de la monarquía en un poema de elogio al nuevo rey, hay que precisar que, en esta ocasión, ¿̇no está Medrano, más bien, augurando un magnífico futuro al «illustre ioven», en 1600, más que juzgando un reinado cuya veintena de años acaba de comenzar? 
en 1605, una canción de Agustín de Tejada Páez ${ }^{3}$ titulada «Al Rey Don Felipe, Nuestro Señor», justo a continuación de la muy conocida canción de Luis de Góngora que comienza "Levanta España tu famosa diestra» ${ }^{4}$. La antología de Espinosa goza de una ordenación que busca la varietas y en ella se insertan diversas series de poemas, por lo que los textos pueden y deben ser analizados no sólo en sí mismos, sino también por la función que desempeñan en la relación con el resto de los poemas de la serie ${ }^{5}$. No me detengo en la función de la canción de Tejada en la organización de las Flores, pues ya ha sido estudiada con precisión ${ }^{6}$, y, por otro lado, mi interés en la canción de Tejada no depende del papel que le asignara el antólogo de las Flores, sino que se apoya en el texto mismo, en cuanto que referente para una labor de imitatio parcial y peculiar que se manifiesta en una oda de Francisco de Medrano. Con todo, conviene comenzar por situar mínimamente la canción de Tejada en el contexto de su primera edición.

En general, la utilidad de Tejada en las Flores procede de su papel de «fiel apoyo con sus contenidos a la poesía grave y religiosa como alternativa al

3. Sobre la biografía y la obra del doctor Agustín de Tejada Páez véanse José A. Muñoz Rojas, "Cuatro cartas inéditas de Agustín de Tejada», Revista de Estudios Antequeranos, 2, 1993, pp. 411-422; José Lara Garrido, «Silva antequerana II (notas de asedio a la poesía antequeranogranadina del Siglo de Oro)", Revista de Estudios Antequeranos, 7, 1995, pp. 129-147 (incluye «Un audaz experimento métrico de Agustín de Tejada Páez», pp. 139-146, sobre el largo poema, recogido en el Cancionero Antequerano, que trata de la Virgen de Monteagudo y «que hibrida épica religiosa y canción heroica», p. 139); Joaquín Roses Lozano, «Agustín de Tejada Páez y la poesía heroica (con algunas notas sobre el magisterio de Herrera)", Revista de Estudios Antequeranos, 9, 1997, pp. 63-88; José Lara Garrido, «Sonetos epicédicos en homenaje del “Divino” Herrera, el rastro tenue de una fama póstuma», en Relieves poéticos del Siglo de Oro. De los textos al contexto, Málaga, Universidad de Málaga, 1999, pp. 111-147 (135-141); José Lara Garrido, «Un poema anómalo en las Flores de poetas ilustres (1605) de Pedro Espinosa. La canción de Mira de Amescua al asalto de Cádiz por los ingleses (1596) y su horizonte de expectativa histórica», Canente, 1, 2001, pp. 123-182; Daniel Cotta Lobato, "La Qualitas Sonorum como recurso expresivo en la poesía de Agustín de Tejada Páez», Canente 1, 2001, pp. 183-231; Belén Molina Huete, "Agustín de Tejada y las Flores de poetas ilustres de Pedro Espinosa», Analecta Malacitana, XXIV.2, 2001, pp. 353-402.

4. Pedro Espinosa, Flores de poetas ilustres, ed. Belén Molina Huete, Sevilla, Fundación José Manuel Lara, 2005, pp. 54-67. Véase, sobre la historia de la antología y sus ediciones, Belén Molina Huete, "Las Flores de poetas ilustres de Pedro Espinosa en sus ediciones del siglo XIX. Cosas de "marquetería literaria”", Canente, 1, 2001, pp. 85-121.

5. Belén Molina Huete, «Manierismo y antología. Las Flores de poetas ilustres de España ordenadas por Pedro Espinosa (1605)», en Gregorio Cabello Porras y Javier Campos Daroca (eds.), Poéticas de la metamorfosis. Tradición clásica, siglo de oro y modernidad, Málaga, Universidad de Málaga-Universidad de Almería, 2002, pp. 95-116. Hay «poemas que tienen razón de ser en sí mismos pero que apoyan y adquieren nuevo sentido en serie», p. 113.

6. B. Molina Huete, «Agustín de Tejada ...», pp. 369-373. 
fatigoso desencanto de amor y camino válido para la fama y la eternidad del poeta: cantar a personas ilustres y hechos gloriosos $[15,83]$ y no a damas desdeñosas; abordar empresas más ennoblecedoras y gratificantes como anunciar la gloria de España $[15,83] »^{7}$. La canción, por su tema heroico, no pertenece ni al dominante tema amoroso de las Flores ni a ninguna de las variaciones importantes, pues sólo hay 9 textos, de los 248 , que se dedican al tema "patriótico» ${ }^{8}$. Sin embargo, al considerar el género elegido (la canción), el texto de Tejada se incluye entre uno de los géneros más representados, el segundo tras el soneto, con un total de 30 canciones, aunque el autor se encuadra, en el análisis de los autores mejor representados, en el «nivel inferior» con cinco poemas 9 . La canción aparece en «la secuencia inicial», que recoge los veinte primeros poemas, y se inscribe en uno de los «cinco asuntos» que al lado del dominante amoroso dan «una idea bastante aproximada de los temas presentados en las Flores» ${ }^{10}$ : curiosamente el tema «heroico-patriótico» se representa por dos textos seguidos (las mencionadas canciones de Góngora y Tejada, que ocupan los puestos 14 y 15 de las Flores). De hecho, el poema de Tejada «forma una subserie con la canción de Góngora dirigida a Felipe II y a la armada contra Inglaterra [...], modelo para tantas composiciones de igual naturaleza» ${ }^{11}$. Conviene retener, en el entramado de imitaciones que persigo, este primer nexo textual, pues si la canción de Tejada sigue muy de cerca el esquema métrico de las estancias gongorinas ${ }^{12}$, Medrano imitará a su vez, aunque con variaciones mayores, el esquema de la canción de Tejada, texto del que aprovecha diversos rasgos para componer un poema diferente en sus intereses, en su extensión y en

7. B. Molina Huete, «Agustín de Tejada...», p. 368.

8. Gaspar Garrote Bernal, «Barahona de Soto en las Flores de poetas ilustres», en José Lara Garrido (ed.), De saber poético y verso peregrino. La invención manierista en Luis Barahona de Soto, Málaga, Universidad de Málaga, 2002, p. 57.

9. G. Garrote Bernal, op. cit., p. 55.

10. G. Garrote Bernal, op. cit., p. 60.

11. B. Molina Huete, «Agustín de Tejada...», p. 369.

12. La relación se podría definir por «un proceso de intensificación total», lo que explicaría el cambio del esquema métrico (ABCBACCDDEefFGHgH) para que acabe en un séxtuple pareado (ABCBACCDDEefFGGHH, con un heptasílabo menos y un endecasílabo más), la ampliación del envío, la abundancia de «los versos cuatrimembres y de manera acumulativa», así como otros caracteres de la construcción del poema: «Desproporcionadamente, Tejada otorga a Espańa el protagonismo en las 7 primeras estancias, como en una gran amplificatio del motivo profético del poeta y de la supremacía española, aunque Tejada hace de la venganza en un nuevo avance intensificador un argumento paralelo al de la defensa de la fe [...] Una sola estancia dedica sin embargo en esta versión a Felipe III como renovación gloriosa del ejemplo del padre, pero implica en cierto modo una nueva intensificación sobre la gloria española que se prolonga en otra generación», B. Molina Huete, «Agustín de Tejada...», p. 370-372. 
su aliento. Para calibrar el haz de posibles relaciones entre los autores que practican la imitatio resulta útil ahora aludir a otro tipo de imitación de Tejada, una «imitación estructural» de Horacio $(\mathrm{I}, 12)^{13}$ en su "Canción a Santiago", pues parece que el caso de Medrano, en su aproximación a la canción «Al rey don Felipe, nuestro señor», sería el inverso: Medrano se apoya en un aprovechamiento de la dicción y manifiesta un desinterés por la dispositio con respecto al modelo que la crítica ha identificado, la canción «Al rey don Felipe, nuestro señor» de Tejada Páez.

Hasta hace poco, las circunstancias que habían motivado la composición de la canción de Tejada Páez las encontraban los investigadores, precisamente por la apropiación de Medrano de varios versos en su oda (cuya proximidad con el hecho histórico es más explícita desde el mismo título de la composición, al menos en alguna de sus fuentes), en la subida al trono de Felipe III, y se databa el poema hacia $1599^{14}$. La lectura del texto parecía sugerir, desde la perspectiva de una profecía cuyos resultados se daban ya por faustos para la corona, una suerte de programa político-militar inmediato: la lucha contra los piratas ingleses y, por ampliación, contra Inglaterra misma. No se trata, desde luego, de una profecía ex eventu, pues sabido es que no produjo la deseada derrota marítima del inglés, ya intentada por Felipe II. Sin embargo, el título buscadamente intemporal (extrańo en lo que parece ser una composición de circunstancias), que también escamotea incluso la precisión del destinatario al dirigir la canción «al rey don Felipe» en un momento de la historia de España en el que no hay más que reyes que lleven ese nombre, permite atisbar que el hecho de armas que se profetiza podría no ser tan claro como parecería. Además, la comparación con los títulos de las otras versiones que conservan el poema de forma manuscrita ${ }^{15}$ asegura que la datación de la canción debe ser anterior. Así, en la Poética silva la canción

13. J. Roses, op. cit., p. 80, que precisa las afirmaciones de Alonso y Ferreres.

14. "Hurtado y González Palencia [...] suponen escrita la "robusta y elevada composición" del racionero antequerano "con motivo de la empresa contra Inglaterra": es decir, la expedición de 1599», D. Alonso y S. Reckert, op. cit., p. 67. Para la cronología actual, más precisa por lo que se explica a continuación, J. Lara Garrido, "Un poema anómalo ...», pp. 131-135 y B. Molina Huete, "Agustín de Tejada...», p. 373, n. 47.

15. B. Molina Huete ofrece no sólo las diferentes fuentes del poema, en el anexo uno (que incluyen, además de las Flores y la Poética silva, dos manuscritos de la Biblioteca Nacional -3.796 , ff. $307-309$ v y 3.920 ff. 338-341v- y el Cancionero de 1628 -f. 42), sino que también, en el anexo dos, transcribe la versión de las Flores y las variantes de las fuentes (pp. 389-396; cito siempre por esta transcripción). Molina Huete valora como versión más acabada la que ofrecen las Flores, aunque de las copias manuscritas considera mejor texto el de la Poética silva. 
se titula "A Felipe II en la jornada de Inglaterra» ${ }^{16}$, lo que indudablemente remite al episodio de la Armada Invencible, y sitúa la redacción del poema hacia 1588, en fecha idéntica o muy próxima a la de la canción de Góngora que la precede en las Flores. Esta hábil difuminación del título encuentra cómodo apoyo en la ausencia de título de la canción de Góngora que precede a ésta en las Flores ( significativamente agrupadas por Espinosa» ${ }^{17}$ ) y sugiere el aprovechamiento intencionado de ambos textos, escritos para un idéntico contexto del pasado, no ya para nutrir la serie y la subserie mencionadas, sino con una finalidad política, pues «la canción de Góngora, desprovista del epígrafe De la armada que fue a Inglaterra con el que figura en diversos manuscritos e impresos, venía a convertirse para un lector de las Flores en una especie de proclamación intemporal del poderío español» ${ }^{18}$. En alguna fuente el colector arriesga una interpretación en el título al suponer que toda la canción, frente a la indeterminación de las Flores, se dirige a Felipe III: "A la jornada de Ingalaterra, dirigida al principe nuestro señor», en el ms. $3.920 \mathrm{BNM}^{19}$. Y es que el compilador del manuscrito no tuvo por qué percibir que la canción estaba originalmente dedicada a Felipe II, y que sólo posteriormente fue adaptada con variaciones mínimas (entre ellas, la indeterminación buscada del título) al comienzo del reinado de Felipe III. Sin embargo, la hábil acomodación del texto a los nuevos tiempos no impide que en el poema se detecte una doble dirección en el destinatario, o dos personae, tal y como explica Lara Garrido, quien defiende con detalle y ajustado rigor que las nuevas circunstancias imponen un único destinatario:

Para su mantenida suasoria de tono pindárico-bíblico, un tejido de tópicos que provienen de la epopeya clásica y de imágenes proféticas y apocalípticas llega a disponerse, con labilidad suma, en dos momentos y diferentes acciones con distinto sujeto, o a través de un sujeto que unifica el conjunto. Situada enunciativamente antes del intento de la gran Armada, la canción conjuga como destinatarios privilegiados

16. Poética silva. Un manuscrito granadino del Siglo de Oro, ed. Inmaculada Osuna, CórdobaSevilla, Universidad de Córdoba-Universidad de Sevilla, 2000, II, p. 230. La canción se copia en I, pp. 249-254. Véase José Lara Garrido, «Los poetas de la Academia granadina (El grupo de la Poética silva)", Del Siglo de Oro. Métodos y relecciones, Madrid, Universidad Europea-CEES, 1997, pp. 231-249.

17. J. Lara Garrido, «Un poema anómalo ...», p. 126. Anuncia José Lara, para la Revista de Estudios Antequeranos, un trabajo sobre la canción de Tejada: «Silva antequerana (V) [Más allá de Herrera y Góngora. Retoricismo epopéyico y estrategias discursivas en una canción de Tejada Páez]».

18. J. Lara Garrido, «Un poema anómalo ...», p. 127.

19. B. Molina Huete, «Agustín de Tejada...», p. 393. 
de su discursividad dos personae. Por una parte, la meditativa y atenta al gobierno universal de sus dominios, que recibe en el envío el compromiso de convertir la victoria en canto épico. Para ella se profetiza en seis estancias el desarrollo pautado de la gran batalla [...] Esta persona representa a Felipe II. Por otra parte, el juvenil «renuevo» de dignidad y título, al que sólo se pide, en una estancia parentética, que abrevie el tránsito hacia la esperanzada promesa como domador guerrero, asegurándole la sumisión a su voluntad de «fortuna tiempo y hado» [...] representa al heredero del trono, el futuro Felipe III. Pero si la situación enunciativa se traslada fuera del marco temporal primigenio, tras la desaparición de Felipe II, el poema tiene como único destinatario privilegiado de su discursividad a la persona que viene a representar al nuevo monarca. La profecía sobre la batalla, el feliz augurio del compromiso épico en el envío y las dos estancias de diatriba -aviso e incitación a la rebeldía- al personificado «reino de Bretaña», renuevan su actualidad en un marco temporal distinto ${ }^{20}$.

La canción se organiza en diez estancias de diecisiete versos (en las que el dominio del endecasílabo sólo deja espacio para dos heptasílabos, proporción que manifiesta el claro predominio de lo heroico en un tono de elevación reforzado por el uso de la asprezza) y un envío de diez. La primera palabra («Tú») permite entrever que, más allá de la simple dedicatoria, la canción buscará la persona real como destinataria de una profecía del éxito militar de la armada española sobre los ingleses. La canción se abre también con un trenzado simbólico entre el rey y el sol para exaltar tanto la coincidencia en la amplitud de las posesiones, como para establecer otra equivalencia más profunda y cara a la exaltación de los reyes, pues el poema encuentra en el monarca el reflejo de una elevada realeza aureolada por la luz y el oro. El ruego explícito y doble de la primera estancia para el «tú» supone esa asimilación en la elevación indomeñable («levanta el rostro de esplendor ornado / y enhiesta la cerviz nunca domada», vv. 7-8) al tiempo que la captatio de una atención para la profecía que el poeta transmite desde el «favorable Febo» («si me escuchas lo que él te profetiza», v. 14). En un ingenioso juego, la condición para que la profecía alcance la «gloria que a los tuyos eterniza» pasa por el cambio del elemento oro (que es también luz y esplendor) por el acero, como se explicita al final: «si, despreciando el oro, ornare acero».

La segunda estrofa se adentra ya en la descriptio (en forma de una enumeración) del vistoso espectáculo de un despliegue militar que es, sin duda, en la época sinónimo y garantía del esplendor de una monarquía y de un imperio. La visión del poeta elige los rasgos que caracterizan ese

20. J. Lara Garrrido, «Un poema anómalo...», pp. 131-132. 
poder militar y los halla en el "caballo con herradas manos», el peto de los soldados, el espolón, los yelmos, los penachos, así como en los signos militares de las "coloradas cruces» y "el vencedor pendón de Santïago» (v. 30), en movimiento; varios de ellos reflejan la luz del sol en sus bruñidas superficies, lo que mantiene el juego con la poderosa identificación de la primera estrofa (pues antes que el Rey Sol por antonomasia parece que hubo otros, reyes y poetas, que utilizaron una metáfora de gran poder ideológico y literario $\left.^{21}\right)$. Y de nuevo, el penúltimo verso se reserva para exponer los elementos determinantes, ahora la causa de la extraordinaria junta: «porque ya del inglés pide venganza» (v. 33).

La tercera estrofa solicita la preparación cuidadosa del material bélico, para pertrechar a «tu gente invicta y laureada», pues en ella la propia virtud es donde se forja («la virtud su virtud acendra y prueba», v. 36). La causa se sitúa en el centro de la estancia, pues se trata de luchar «contra el reino que un tiempo honró a san Jorge» (v. 43), en una contraposición en la que se enfrentan «el espańol supremo / contra el gélido inglés» (vv. 46-47). Significativamente, como se verá, Medrano aprovecha este final sonoro de la estrofa (que pondera la fuerza del «atanor de bronce») así como gran parte de los versos de la cuarta estrofa en donde se concentra, en elevada dosis, el movimiento bélico, del que se destaca, para ponderar sus efectos destructores, el ruido (como signo del poder que se libera), al tiempo que se desarrollan algunas visiones de enfrentamiento naval. Se incluye, también hacia el centro de esta estrofa cuarta, a los enemigos, ahora desdoblados en dos («al inglés rojo y al soberbio turco», v. 60), aunque unidos por su herejía. Se cierra la estancia con una condición necesaria para que la profecía se cumpla: «Al duro banco el brazo hereje amarra, / para que el mar con remos are y barra» (vv. 67-68). A su vez, esta estrofa prepara la visión anticipada de la derrota del inglés que se desarrolla en la quinta estancia, en donde el rojo de la sangre enemiga es un elemento plástico importante, para construir también la imagen de la humillante derrota (ya adelantada por el final de la cuarta estancia, en donde remar-actividad ya de por sí infame, para la ideología de la época, que a menudo recae sobre forzados- se asimila a otras igualmente bajas e inofensivas como arar y barrer). Los enemigos no sólo quedan exangües, con sus símbolos militares y nacionales arrastrados, sino que su maquinaria militar estará destruida o inservible. Esta derrota

21. «As a solar king, Philip IV recalls the symbolism of the sun in neo-platonic treatises, where it stands for the unity of being, the primordial deity whose rays or emanations form the world», Frederick A. De Armas, "The Play's the Thing”: Clues to a Murder in Villamediana’s La gloria de Niquea», Bulletin of Hispanic Studies (Glasgow), LXXVIII.4, 2001, pp. 447448 . 
se continúa en la estrofa sexta con una nueva visión de los muertos, ahora en cuanto cuerpos sin vida (y no sólo metonímicamente implicados en la visión de la sangre): «con los cuerpos que nadan, no nadando / por estar de la vida despojados» (vv. 87-88), convertidos en una suerte de macabro adorno de la orilla ${ }^{22}$. Además se mencionan, para completar la imagen del triunfo, los «ricos trofeos de inmortal memoria» (v. 93), más las manifestaciones rituales de alegría, "con que se turbarán esos turbantes / de los bárbaros fieros arrogantes» (vv. 99-100).

Tras la necesidad de la batalla, tras la enumeración de los preparativos militares, tras la batalla en sí, tras la imagen de la derrota de unos y el éxito de otros, Tejada incluye la estrofa séptima que es una larga enumeración de material bélico que ocupa catorce versos seguidos. Además de la exhibición de una potente técnica poética que despliega una enorme riqueza semántica, la enumeración sirve para ver el éxito ("verás entonces a tus pies rendidos», v. 103) en una enumeración plástica de poder aplastante e irrebatible, una constatación del triunfo que se cierra con los prisioneros, recogidos metonímicamente en «sus cervices duras», opuestas de manera absoluta al verso ocho ("y enhiesta la cerviz nunca domada») con que se abría el poema $^{23}$.

Sólo entonces se recupera el «tú» con que se iniciaba el poema, ahora en la estancia octava (por más que nunca se haya perdido la referencia a la segunda persona en la forma de posesivos, otros pronombres y desinencias verbales), para resaltar la juventud del nuevo monarca, que es «pimpollo tierno y tierna planta, / Tercero en el nombre del que fue Segundo» (vv. 120-121). En la primera versión «Y tú» supondría un evidente cambio de destinatario, en el que se valoraba la juventud del futuro monarca, a quien también se instaba a armarse de acero, como al padre. En la última versión, la fusión de las dos personae permite respetar el «Y tú» inicial de esta estrofa porque ahora constata la recuperación de un diálogo directo con el «tú» del comienzo,

22. Compárese con estos versos de la mencionada canción de Góngora: «fía que en sangre del inglés pirata / teñirá de escarlata / su color verde y cano / el rico de ruïnas oceano; / y aunque de lejos con rigor traídas, / ilustrará tus playas y tus puertos / de banderas rompidas, / de naves destrozadas y hombres muertos» (vv. 27-34). «Aunque tanto ellos [Cervantes y Lope] como don Luis recogen viejos tópicos del género (la diestra justiciera, la voluntad divina, el fulgor de las armas, el agua ensangrentada, las banderas al viento, "los árboles portátiles de España”...)», Luis de Góngora, Canciones y otros poemas en arte mayor, ed. José María Micó, Madrid, Espasa-Calpe, 1990, p. 61.

23. J. Lara Garrido en un apunte sobre la "taracea» de Medrano señala que el término cerviz (y su utilización bíblica) sirve a Tejada para contraponer en su diferencia a españoles e ingleses, y que Medrano mantiene sólo la segunda mención: «hasta que el galo o el inglés molesto/ rindan al yugo tuyo el cuello enhiesto», «Un poema anómalo...», p. 163, n. 79. 
del que se destacan aspectos personales que en la primera estrofa estaban ausentes ante la preferencia por el tema de la fuerza y la amplitud de un poder que se identificaba con el de Febo. Sólo el conocimiento de la existencia de las dos versiones permite aquilatar que en la primera estrofa, en el primer verso, el "heroico pecho» debía remitir a alguien que tuviera detrás un background adecuado, por más que en la expresión de la admiración real o, más simplemente, en la elevación del tono del panegírico el «heroico pecho» pueda suponerse de antemano y, por lo tanto, ser plenamente aplicable a un joven Felipe III. La lucha contra la soberbia de «quien goza poco del hermoso Febo» (v. 125) remite simbólicamente a la ya señalada identificación y desdoblamiento del rey y de Febo (también al comienzo del poema), pues el dios y astro rey no pertenece a la grisura del mundo anglosajón ${ }^{24}$. Al mismo tiempo, la lucha es una forma de aumentar «el bien al mundo», una forma de prometer «nueva gloria y siglo nuevo», por lo que la voz poética insta al monarca, una vez que la estrofa ha superado retóricamente la dificultad que supone un monarca joven a base de los argumentos mencionados, para que acelere el proceso y «de acero claro / cubras el cuerpo raro» (vv. 129-130), sin temer «hado, tiempo, ni fortuna», pues los tres se plegarán a su voluntad.

La canción acaba, después de este cierre que es la estrofa octava, y antes del commiato, con un cambio de destinatario, pues la voz poética busca, tras el aterciopelado trato que ha supuesto esta estrofa octava, la condena, la imprecación del enemigo, personificado en el "gran reino de Bretaña» ${ }^{25}$. Se enhebran entonces diversos motivos en los que no me detengo (la contraposición de la «feroz braveza» de la nación con la «mujeril vileza» de la reina, la hipotética esperanza en la vuelta del rey Arturo, la persecución y martirio de los auténticos cristianos, etc.). El envío supone la interrupción momentánea de un discurso que es un «vuelo», a la espera de que la profecía se cumpla, pues entonces el poeta será quien cante la victoria y alcance, a su vez, una gloria ("que yo he de ser Virgilio de tal Marte», v. 175) que llegue hasta el último rincón ${ }^{26}$.

24. Compárese con estos versos de la canción de Góngora: «y a la de tus arneses fiera lumbre, / con mortal pesadumbre / ojos y espaldas vuelvan / y, como al sol la nieve, se resuelvan; / o, cual la blanda cera, desatados / a los dorados luminosos fuegos / de los yelmos grabados, / no menos que de fe, de vista ciegos» (vv. 10-17).

25. Compárese con la tercera estancia de la canción de Góngora (vv. 36-52).

26. En la poesía panegírica de unos literatos a otros, «un subtópico importante, que provenía de Salustio, consistía en señalar que en España no faltaban guerreros, sino escritores que dieran testimonio al futuro de sus hazañas: Herrera participó de un motivo que fue tan reiterado en la literatura de aquellas centurias como el que entonaba un lamento por la falta de poetas épicos», Gaspar Garrote Bernal, «La retórica de los Poemas Laudatorios de poetas en los siglos XVI y XVII», en J. Antonio Hernández Guerrero (ed.), Retórica y Poética, Cádiz, 
La canción no puede ser considerada sólo como un panegírico, aunque sea evidente la exaltación -en el momento de su enunciación- del rey (y del futuro rey o del nuevo rey -en la versión de las Flores), pues trata con detalle del éxito de las armas españolas sobre las inglesas en una profecía que, aunque no se cumplió en absoluto, adopta el tono heroico que antecede a un hecho de armas que se presume glorioso, además de ceder un protagonismo notable al carácter herético del enemigo.

En las valoraciones de la canción parece percibirse el eco de la que Cervantes estampó entre los elogios del Viaje del Parnaso: «[...] Éste es Tejada, / de altitonantes versos y sonoros, / con magestad en todo levantada ${ }^{27}$. El lector percibe enseguida y sin dificultad la importancia que a los aspectos sonoros concede el racionero de Granada, que para D. Alonso era rimbombante y que para Cotta se conecta con otro concepto más retórico: "Tejada, en cambio, entenderá la asprezza, al igual que los teóricos italianos del Cinquecento, como la cualidad principal y condición sine qua non del poema épico, género supremo del decir poético [...] Quizá ninguna canción como la dedicada al rey don Felipe en su armada contra Inglaterra presente versos tan sobrecogedoramente ásperos y efectivos ${ }^{28}$. De la decena de estrofas se suele destacar la séptima estancia, que "ha quedado como muestra delirante del amplio repertorio instrumental bélico en la época, a base de estructuras binarias, ternarias, cuaternarias» ${ }^{29}$. Lara Garrido pondera con finura, en esta «extraordinaria canción», la variación del destinatario y el cambio que supone la aparición de la canción en antologías más de diez años después de las circunstancias que motivaron su creación: «en pocas ocasiones tan mínimos y puntuales retoques pueden provocar cambios de tal calibre en una creación artística. Lejos de pensar que se trata de un expediente resolutivo para el rescate sin disonancias anacrónicas de su magnífica canción, Tejada nos revela hasta qué punto podía ser equivalente la intentio operis en el horizonte de 1587 y en el de 1605 (más ajustadamente entre 1598 y 1603)» ${ }^{30}$. Otras valoraciones parecen perder de vista los elementos esenciales tanto de la poesía de Tejada Páez como de esta canción en concreto ${ }^{31}$.

Seminario de Teoría de la Literatura, 1991, p. 163.

27. Miguel de Cervantes, Viage del Parnaso. Poesías varias, ed. Elías L. Rivers, Madrid, Espasa-Calpe, 1991, capítulo II, vv. 193-195. Los versos aparecen citados en el trabajo de J. Roses, quien comenta: "Ciertamente, la poesía del Racionero encarna un ideal de sublimidad heroica y elevación tonal», op. cit., p. 69.

28. D. Cotta Lobato, op. cit., pp. 188 y 191.

29. Pablo Villar Amador, Estudio de las «Flores de Poetas Ilustres de España» de Pedro Espinosa, Granada, Universidad de Granada, 1994, p. 175.

30. J. Lara Garrido, «Un poema anómalo...», pp. 137 y 134.

31. «En esta canción, a veces, el amaneramiento excesivo asalta a cada paso, con su ralo 
Conectada con la canción de Tejada Páez está la oda IV de Medrano, que lleva el epígrafe "A Filipo III en la misma entrada», a continuación del soneto VII, «A la reina dońa Margarita entrando en Salamanca» ${ }^{32}$. La oda está "configurada como un epinicio al futuro triunfo de las escuadras de Felipe III contra los franceses e ingleses» y en ella «el sentimiento patriótico se entreteje con el religioso" ${ }^{33}$. Dejando de lado, por el momento, la coincidencia de destinatario (con las peculiaridades ya comentadas en el canción de Tejada) así como cierta comunidad temática (y otras relaciones de las que me ocupo enseguida), la relación entre ambos poemas queda asegurada por «las notables semejanzas» entre uno y otro que advierte Agustín del Campo y que publican Alonso y Reckert en su edición ${ }^{34}$ :

\section{Tejada Páez}

y azote el viento vago

el vencedor pendón de Santïago

(29-30)

escupa con relámpagos horrendos, rayos de plomo y truenos estupendos. $\mathrm{Al}$ atambor se le reviente el parche, y el cañón a la trompa le reviente $\mathrm{y}$ al aire atruene su sonoro aliento; y adonde el pie de su soldado asiente cuando tu vitorioso campo marche,
Medrano

al vencedor pendón de Santïago, que desde el aire vago escupirá de rayos un diluvio [cfr. v. 38:

escupiendo de sí rayos ardientes; cfr. v. 93:

rayos, truenos, relámpagos, dragones]

Del hispano atambor rimbonbe el parche,

prosaísmo y la busca inútil de una originalidad que al romper el decorum cae en lo farragoso y fácil. El dinamismo al que aludíamos anteriormente en este autor, alcanza una alta cota en esta canción gracias al aspecto verbal (est. 3), o a la construcción polisindética (est. 4) o a la aduinctio asindética (est. 7), que acaba disgregándose en una enumeratio caótica de argumentos», P. Villar Amador, op. cit., pp. 176.

32. Sigo, en todas las citas de Francisco de Medrano, la modélica edición de Diversas rimas, ed. Jesús Ponce Cárdenas, Sevilla, Fundación José Manuel Lara, 2005, pp. 26-32.

33. Soledad Pérez-Abadín, «La oda en Francisco de la Torre, Fray Luis de León y Francisco de Medrano», en Begońa López Bueno (ed.), La oda. II Encuentro Internacional sobre Poesía del Siglo de Oro (Sevilla-Córdoba, 16-21 de noviembre de 1992), Sevilla-Córdoba, Grupo PASO, etc., 1993, p. 273.

34. D. Alonso y S. Reckert, op. cit., pp. 66-67: incorporan las variantes de R en los versos 35 (mira en los charcos), 36 (portátiles casas) y 72 (y el aire atruene la). Sigo las lecturas de las ediciones de Belén Molina Huete y Jesús Ponce Cárdenas, ya citadas. 
con la sangre enemiga esté sangriento: Cuando puebles el húmido elemento y con movibles casas abras surco al inglés rojo y al soberbio turco, (50-60) y al aire asorde tu sonora trompa, el acero luciente al sol deslumbre, tu Armada la salobre plata rompa, [cfr. Tejada 72]

mientras que por la tierra el campo marche vitorioso, cual tiene de costumbre; (71-76)

mira en el golfo de crespada plata mil portátiles torres fabricadas (35-36)

Verás risueño entonces sus banderas, prospere el cielo agüeros tan felices, besar la tierra humildes para ejemplo, arrastradas sus naves infelices a jorro por tus ágiles galeras (99-103)$$
\text { (9)-103) }
$$

que la salobre plata la arreboles con su herética sangre por venganza, y des rojo color al blanco charco. Su nao mayor tu más pequeño barco ajorro arrastrará, y aun sus banderas besarán de la mar las aguas fieras; (72-77)

A la vista de esas «semejanzas» entre diecinueve versos de Tejada Páez y dieciocho de Medrano, Alonso y Reckert se deciden por la prioridad de Tejada con esta argumentación:

1) los pormenores en que coinciden los dos poetas forman en Tejada unidades homogéneas, mientras que Medrano los ladea y baraja; 2) en tres casos (vv. 35, 36 y 72 ) la primera lectura de Medrano (o sea, la de R) resulta intermedia entre una expresión empleada por Tejada y la lectura definitiva de Medrano (la de P) ${ }^{35}$.

Como ya he indicado, hoy es imprescindible corregir la cronología de la canción de Tejada Páez y matizar que el texto ha sufrido una notable transformación, por más que los indicios textuales sean mínimos, entre la fecha de su hipotética escritura, en torno a 1588, y la fecha de su publicación en las Flores de poetas ilustres, en 1605. La oda o canción de Medrano, por el contrario, se fecha, según Alonso, «con toda exactitud: corresponde a la primavera o primeros días del verano de $1600{ }^{36}$, pues la circunstancia que la motiva parece bien conocida. Además Medrano escribe un par de sonetos sobre la misma visita real a Salamanca, de modo que la oda IV, composición de circunstancias, forma una serie temática con los dos sonetos (uno dirigido

35. D. Alonso y S. Reckert, op. cit., p. 67.

36. D. Alonso, op. cit., p. 231. 
a la reina dońa Margarita, y otro dedicado a Felipe III) que conmemora la visita de los monarcas a la culta ciudad de Salamanca.

Es obvio que, en principio, no cabe sorprenderse de que Medrano imite a otro poeta, y no sólo porque la imitación es un elemento esencial de la poética de los Siglos de Oro, sino también porque Medrano es uno de los más destacados adaptadores de las odas de Horacio, en cuya imitación consigue unos soberbios resultados (por ejemplo al tratar de aproximarse a los efectos rítmicos de las estrofas latinas en su adecuación a las españolas):

Toda la poesía de los siglos XVI y XVII es de imitación. La de Medrano también. Imitación significa seguimiento, ya más de lejos, ya más de cerca, $\mathrm{Y}$ estos dos matices se encuentran en la obra de Medrano; aunque la gran cercanía a Horacio, en las odas, resalte más a primera vista, para nosotros. Pero se puede ser original en la imitación: Medrano es un imitador de una enorme originalidad ${ }^{37}$.

Se trata de una imitación creativa o creadora que se aleja, dentro del amplio abanico de posibilidades que se esconde bajo el común término de imitatio, de la copia o de la mera repetición ${ }^{38}$. Sin embargo, resulta interesante ver qué modelos sigue Medrano en sus tres poemas dedicados a la visita real a Salamanca y qué tipo de imitación practica.

El soneto VII de Medrano («Borde Tormes de perlas sus orillas») está dedicado, según una fuente, «A la reina doña Margarita entrando en Salamanca», a la misma visita que se conmemora en la oda IV, que tuvo lugar, según anota Alonso, «a fines de junio y principios de julio de 1600». El editor subraya también que el soneto es imitación del otro muy conocido de Góngora, de 1582, «Raya, dorado Sol, orna y colora» ${ }^{39}$ : «La imitación es tan próxima que la distribución formal es idéntica (aunque con variación de contenidos) a través de cuartetos y tercetos», incluso en las peculiaridades de la distribución de los elementos diseminados que se recogen al final «tan fiel es Medrano al esquema, que conserva exactamente la misma irregularidad de distribución» ${ }^{40}$. Sería fácil pensar que se trata de una técnica

37. Francisco de Medrano, Poesía, ed. Dámaso Alonso, coord. María L. Cerrón, Madrid, Cátedra, 1988, p. 67.

38. Ángel García Galiano, La imitación poética en el Renacimiento, Kassel, Universidad de Deusto-Reichenberger, 1992.

39. Sobre las huellas de Góngora en Tejada véanse B. Molina Huete "Agustín de Tejada...», p. 357, n. 11 y p. 383, y Gregorio Cabello, «Un ejemplo de imitación de Góngora a través de Medrano: Triunfo de Fénix», Barroco y Cancionero. El "Desengaño de amor en rimas» de Pedro Soto de Rojas, Málaga, Universidades de Málaga y Almería, 2004, pp. 630-636.

40. D. Alonso y S. Reckert, op. cit., p. 59. Alonso considera de interés, para sus fines, 
que Medrano emplea para esta poesía de circunstancias, impelido quizá por la premura, por un encargo tardío, por una falta de motivación o de interés, o por otras razones. En todo caso, no deja de sorprender tanta proximidad estructural, que no se da en la oda IV donde la imitación procede mediante un aprovechamiento distinto del vocabulario y los versos.

$\mathrm{Si}$ a la reina se dedica el soneto VII, el siguiente canta al rey durante su visita a Salamanca, al igual que la oda IV, de manera que parece que hay una distribución de asuntos entre las tres piezas dedicadas al mismo motivo y que Medrano busca, además de variar, una exaltación de la cabeza de la monarquía ${ }^{41}$. El soneto VIII («Soberano Señor, cuyo semblante») lleva esta rúbrica: "Al mismo entrando en las escuelas de Salamanca», que en otra versión cambia por: «En la entrada del Rey don Felipe Tercero en Salamanca con la Reina doña Margarita. Al Rey nuestro señor». El soneto, al margen de la doble obligación del monarca (representada por los modelos mitológicos de Marte y Apolo, aunque desarrolle mucho más la implicación guerrera de un monarca), parece apropiado motivo para recibir a un rey en una ciudad como Salamanca. Pero el soneto también incide en el motivo de los modelos familiares que ya está en la oda, y que la separa del texto de Tejada, pues aquí se mencionan explícitamente al padre y al abuelo, creando, al mismo tiempo, la necesaria legitimación de la descendencia en una monarquía, que es por supuesto física o biológica y que debe deseablemente ser, al menos en la literatura, ideológica. Se ve claramente que se trata del comienzo de un reinado y que se proponen modelos de conducta al nuevo rey, más que exaltar los hechos que aún no han ocurrido. Alonso, que estudia la «cierta rudimentaria correlación bimembre» de Marte-Apolo, padre-abuelo, pazguerra, relaciona el texto con otro soneto dedicado a Felipe III, el VI («Majestad soberana, en quien el cielo», dirigido "Al rey don Felipe III luego que heredó y se casó»), que alude al matrimonio del rey, en 1599 y que muy claramente exalta, como elogio y como tarea, un futuro de esplendor, semejante al de los antepasados («émulo de tu padre y de tu abuelo», v. 5). La citada dualidad es la que se maneja, intencionadamente de forma menos equilibrada en la oda, pues se juega con la doble imagen del monarca pacífico

la proximidad, entre otras cuestiones, "porque nos indica un minucioso estudio de estos procedimientos de recolección [...] El sentido concreto, la materia, ha cambiado al pasar del de Góngora al de Medrano; pero la forma, la estructura correlativa, rítmica y aun sintáctica, es la misma. Hemos de repetir muchas veces esta observación y con mejores ejemplos», p. 215. No es, por otro lado, un soneto de amor el de Medrano, sino de "galantería cortesana", p. 101, n. 2.

41. D. Alonso y S. Reckert anotan que el orden de las tres composiciones es inverso en otra fuente (op. cit., p. 70). 
en Salamanca y guerrero en sus dominios en general, para alcanzar un final gozoso y anticlimático tras el éxito ante los enemigos. La carga ideológica del soneto VIII y de la oda se puede cifrar en el último endecasílabo del soneto: "amar la paz y ejercitar la guerra», con un vaivén temporal entre el "ahora» (que incluye a Salamanca, el modelo del padre y la anterior imagen de Apolo) y el «después» (en un espacio sin determinar, el modelo del abuelo y previa imagen de Marte) que se corresponde con la arquitectura del soneto: Marte y Apolo ocupan cada uno, y en este orden, un cuarteto, mientras en los tercetos se proyecta, de forma admonitoria («honra», «sigue») la imagen del padre (asociada a las «letras», las «leyes» y la "paz») y del abuelo (en una imagen más complicada, aunque claramente se apunta un elemento guerrero ausente en el primer terceto), invertidas en la cronología para dar paso al orden del endecasílabo final, por más que no suponga una ordenación cronológica sino moral: «amar la paz y ejercitar la guerra». Este programa de "lo que es propio de los reyes» se desarrollará a lo largo de los ciento veinte versos de la oda, ampliando decisivamente y con detalle las tareas guerreras que aquí sólo se mencionan, en una suerte de admonición y profecía vaga que augura el triunfo del nuevo rey en su complejo rol, lo que se presenta como un elogio que es una doble salutación, por su visita a Salamanca y por su acceso al trono.

Junto a la detectada influencia de Tejada en la oda IV, hay que recordar las más lejanas de Herrera y Góngora (como dice D. Alonso) y una reminiscencia de fray Luis (en los vv. 25-26). Pero, ¿es encuadrable dentro de la imitación el proceso de apropiación de los versos de Tejada? Quizá haya que formularse antes otras preguntas: ¿Por qué se apropia Medrano de versos de Tejada? ¿Cómo le llega el texto que luego se publicará en las Flores? Desde luego las fechas de nacimiento de ambos autores son próximas: en 1567 nace Tejada y en 1570 Medrano. Pero ¿`son amigos? ${ }^{22}$ Si es así, eso quizá justificaría el homenaje. Es posible que Medrano perciba la relación de la canción de Tejada con la de Góngora, que también estará recogida en las Flores, y quizá también conozca la reapropiación de Tejada de su canción para adaptarla a la nueva época (aunque los testimonios conservados no parecen sustentar esta suposición, dentro de unas fechas que no son más que aproximadas: las

42. No parece documentarse por ningún lado ni la amistad ni siquiera un encuentro. No obstante, para la valoración de la sensibilidad sevillana de Medrano véase Antonio Prieto, $\mathrm{La}$ poesía española del siglo XVI, Madrid, Cátedra, 1987, II, pp. 401-412. Sería especialmente útil precisar, si fuera posible, dónde encuentra Medrano la canción de Tejada, en qué manuscrito y en qué lugar de España (recuérdese el «desarraigo» impuesto por la Compañía de Jesús, aparentemente por motivos de salud, y que lleva a Medrano de Andalucía a Salamanca y a Valladolid; F. de Medrano, Poesía, ed. D. Alonso, coord. M. L. Cerrón, pp. 20-21). 
Flores, impresas en 1605, están listas en 1603; la Poética silva «pudo estar concluida hacia $1602 »^{43}$ ) y se limite a seguir un modelo de imitación en el que le ha precedido, en dos momentos al menos, el propio Tejada Páez. Pero una cosa es imitar algunos procedimientos gongorinos y otra apropiarse de los versos de otro poeta, por no tratar de la legitimidad de un poeta para reelaborar sus propios versos. Frente a una cronología borrosa, Lara Garrido deduce con claridad diversos hitos cronológicos:

La versión de la Poética silva viene a demostrar que alrededor de 1600 todavía Tejada no había reescrito su juvenil poema [...] Se hace más justificable de esta forma la osadía con la que Medrano taraceó la canción del antequerano. A fin de cuentas se trataba de una composición añeja, cuyo eco parecería menos perceptible que el de un poema referido a una acción tan sonada y reciente como la intentona invasora de 1599. Es más: la contrahechura de Medrano equivale a un argumento de peso contra la posibilidad de que hacia 1599 Tejada hubiera retocado su canción. Las expediciones de 1601 y 1602, en proximidad a la solicitud de Espinosa de material poético para sus Flores, ganan enteros como referente histórico que daba cobertura a los retoques actualizadores en el poema ${ }^{44}$.

El poema se compone de ocho estrofas de catorce versos más el envío de ocho versos. La distribución de las rimas (ABCBACCDEEDdFF) se parece mucho, según D. Alonso, a la de las estancias de Tejada Páez: «idénticas en los primeros ocho versos (luego, en el rimbombar final, Tejada vence fácilmente a nuestro poeta) ${ }^{45}$. El mismo D. Alonso comenta antes con socarronería la utilidad de la estrofa: «Es una estrofa buena para el estruendo, con su final pareado, como un acorde de gloria. Muchas sonoridades le sacó Medrano con escogidas palabras. Sí, sí, rimbomba, rimbomba. Pero, gracias a Dios, no era su camino el de poeta áulico» ${ }^{46}$.

43. I. Osuna, op. cit., I, p. 20. Además comenta que «los poemas de la colección parecen situarse en un período no muy extenso, aproximadamente entre 1595 y 1601, aunque no se puede descartar por completo la presencia de poemas anteriores o ligeramente posteriores».

44. J. Lara Garrido, «Un poema anómalo...», p. 133, n. 23.

45. D. Alonso y S. Reckert, op. cit., p. 67.

46. D. Alonso, op. cit., p. 246. Por el contrario, D. Cotta Lobato valora de manera muy diferente las aportaciones de Tejada Páez, y en el caso de la canción que me ocupa considera que «rebosa de esa fuerza, de ese espíritu heroico que estremece en la canción dedicada al rey Felipe en su expedición naval contra Inglaterra. Y todo gobernado por una inteligencia capaz de extraer su máximo jugo a la materia prima de la poesía: el sonus», op. cit., pág. 189. Por otro lado, el pareado se utiliza con muchísima frecuencia como cierre de la estancia, aunque Tejada emplea un pareado séxtuple y Medrano uno triple. Cervantes se vale de un esquema que acaba 
El título de la oda de Medrano es mucho más explícito necesariamente, puesto que la pieza tiene un marcado carácter circunstancial que, como es frecuente en la modalidad, no trata de ocultar (sólo el testimonio $\mathrm{R}$ da menos datos en su exigua brevedad: "Al Rey»). La primera estrofa se dedica a una bienvenida en la que se subrayan las notas de juventud (de hecho los dos primeros versos insisten, desde las dos primeras palabras, «ilustre joven», en los dos rasgos más significativos del nuevo monarca: su prosapia y su juventud), de realeza, de fuerza (del brazo al regir el cetro y, muy significativamente, empleado en la caza), y se incluye una referencia al "padre augusto». Contrapone la violencia o fuerza, por más que justa, de la realeza a la "pacífica toga", consonante con la ciudad que le rinde su admiración («manso escucha la lira», v. 12) ${ }^{47}$ : los adjetivos ("gozoso», «pacífica», «alegre», «manso",...) remiten a ese cambio que debe imponer la visita a Salamanca. El motivo del oro que ciñe la sien del monarca se retoma más tarde como símbolo del necesario trueque de oro por acero (v. 59), y ya está presente en la contraposición entre la corona de oro y el acero del venablo.

A continuación, se desarrolla la grandeza del monarca en matizado contraste con su juventud, motivo este último con el que se inicia una estrofa (II) también dividida en dos: el reconocimiento de la juventud del monarca, al que ańade la consideración del valor de la experiencia, deja paso a la invitación para que el rey advierta la grandeza de sus posesiones. Los versos se deslizan hacia un tono admonitorio que conjuga, como no puede ser menos dadas las circunstancias, el reconocimiento de una virtud sin duda heredada del padre aunque es también característica de la esencia teórica de la monarquía: "prudente advierte, oh sin igual monarca» (v. 23). El juego temporal que se adelantaba al final de I («goza en julio del mayo que te ofrece», v. 13, en donde el primer mes parece una referencia circunstancial, mientras mayo se reviste de un valor simbólico), ahora se completa con el símbolo de octubre («si aún están lejos del lluvioso octubre», v. 18), que sirve de florido engarce entre ambas estancias, con un manido juego simbólico de dos meses representativos tanto de sus respectivas estaciones como de las edades del hombre, juego que permite un elogio que pueda superar esa obvia falta de experiencia, "pues los [frutos] da el seso y el valor mejores» (v. 20). Así, la oda de Medrano, a diferencia de la canción de Tejada, debe partir de la aceptación de la juventud del monarca e irse aproximando, mediante un elogio poco específico de Felipe III y aplicable a cualquier monarca en sus

en un doble pareado en la «Canción primera a la Armada Invencible» (ABCABCcDEEDFfGG), Poesias completas, II, ed. Vicente Gaos, Madrid, Castalia, 1981, pp. 359-364.

47. La contraposición entre la trompa y la lira es tópica. Está en la canción de Góngora: «Canción, pues que ya aspira / a trompa militar mi tosca lira,» (vv. 87-88). 
comienzos (siempre desde el convencimiento de las bondades que poseen los representantes de esa forma de organización política), hacia los motivos militares, tan asociados, también por necesidad, a la consecución de la gloria.

En esta gradual aproximación o deslizamiento desde la bienvenida (y desde el reconocimiento de las virtudes de un rey joven) ahora (III) se pide al rey que aplique "sabio el oído», pues así escuchará los tambores de enemigos («del fementido galo e inglés pirata», v. 31), en contraste con la percepción visual de «flores» en el «aire sutil enriquecido», que, según D. Alonso, representan a Francia. El ruego para que mire se completa con otra visión, dentro de un espíritu militar embellecido retóricamente: «mira en el golfo de crespada plata / mil portátiles torres fabricadas / y en la campaña Joves mil valientes / escupiendo de sí rayos ardientes» (vv. 35-38), aunque las imágenes se tornan claramente negativas al final de la estancia cuando se descubre que su intención persigue «escurecer el nombre de Filipo» (v. 42). Esta descriptio es muy amable, pues apela a unos sentidos que miran el aire y que descubren una naturaleza ennoblecida por metáforas transparentes («el golfo de crespada plata») o un material bélico tocado por la mitología e incluso un desdoblamiento de cuerpo y alma que pondera la determinación de los soldados ¡enemigos! («cuerpos de acero y almas de ira armadas», v. 39). Más grave ideológicamente puede ser la proximidad entre la flores francesas y la «florida adolescencia» del joven monarca, por más que la integración poética o retórica de los motivos esté conseguida. Frente a Medrano, Tejada no proporciona una visión idílica o exaltada de los enemigos, sino que sólo aparece su descriptio una vez derrotados, con lo que la imagen gana en fuerza ideológica, en seguridad y exaltación nacional, que es, sin duda, uno de los objetivos de la canción heroica. Por eso, Medrano, que en esta estrofa utiliza alguna de las imágenes de Tejada, ofrece una visión muy distinta pese a todo- de la de Tejada, pues en éste el mar plateado sirve de imagen sumamente plástica de la derrota inglesa al insistir en el rojo de la sangre enemiga sobre ese fondo ("que la salobre plata la arreboles / con su herética sangre por venganza, / y des rojo color al blanco charco», vv. 72-74 ${ }^{48}$ ).

48. Como en otros casos, en los que no puedo detenerme, Tejada Páez imbrica los motivos a lo largo de la canción. El contraste entre los colores de la sangre y la plata se encuentra ya en el verso 40 («que en sangre tińa su color de plata» la espada) y se vuelve sobre él, con variaciones en los versos 74 («y des rojo color al blanco charco») y 163 («enrubiando de mártir sangre santa»). El entretejido de imágenes a lo largo de su extensa canción separa el texto de Tejada de la canción de Góngora, más allá de las puntuales coincidencias («de los yelmos grabados», v. 16 de Góngora, «y relumbren al sol yelmos grabados», v. 31 de Tejada; J. M. Micó, p. 64, nota). Sopésese también la importancia que el sol posee en Tejada al 
También IV comienza con la admonición del imperativo, ahora repetida («alienta, alienta tu nativo instinto», v. 43), y que exalta el arrojo tanto de los españoles como de los antepasados, a los que se recuerda, detrás de un apelativo que mitiga la fuerza de la imagen con el adjetivo ( «generoso león» ${ }^{49}$ ). La mención de los antepasados carece de sentido en la canción de Tejada, dirigida a un monarca maduro, en su primera versión, pero en Medrano puede resultar imprescindible ampliar la materia poética con este recuerdo de las viejas glorias familiares, aunque es, al mismo tiempo, un motivo que insiste en la falta de experiencia del nuevo rey, por más que intente una suerte de transubstanciación, por la fuerza poética, para aumentar el valor o la motivación del joven monarca al recordarle que se debe a una estirpe. Así, Medrano recuerda a Carlos V y la memoria «de un Juan o de un Alfonso o de un Fernando» (v. 48) ${ }^{50}$. Más interés posee, probablemente, la inclusión de mujeres en la nómina heroica, aunque sólo se explicita una (Isabel): todas ellas, con sus armas femeninas, triunfaron sobre los musulmanes y los franceses («que a sus pies derribaron con la rueca / el orgullo del ídolo de Meca / y con sus fuerzas Galia y sus haberes / temió sus alfileres», vv. 51-54). Es evidente que el triunfo con la «rueca» y los «alfileres», además de mantener cierto decoro femenino de obligado acatamiento en la sociedad del Antiguo Régimen, supone una minusvaloración ideológica del poder de los enemigos, al menos de estos dos y no, significativamente, del inglés, de modo que la derrota de los enemigos es un auténtico «ultraje». Pero también es cierto que la imagen es quebradiza en el elogio del monarca al que se ofrecen como ejemplo de valor y fuerza estas diferentes y casi innominadas mujeres, que redondean "gloria eterna de tu real linaje» (v. 56).

Tras la descriptio (III) y el elogioso recuerdo de la estirpe (IV), se invita al monarca al combate, en una estancia (V) que mantiene el uso del imperativo como comienzo («Ponga ya al malo horror»), aunque ahora no vaya dirigido directamente al monarca. Se refuerza la idea de que se trata de una empresa justa, y se invita al rey a cambiar el oro por el acero («descińa el oro y el acero oprima», v. 59) sin que por ello pierda carácter regio, pues el cambio

comienzo de su canción, o el valor del motivo del sol transformado en II para apreciarlo en el reflejo de las armas a lo largo de toda la estancia (frente a sólo dos versos de Góngora: «al claro resplandor de tus espadas / y a la de tus arneses fiera lumbre», vv. 9-10; o a cuatro de Cervantes: «haz los reflejos y vislumbres bellas / que cual claras estrellas / en las lucidas armas el sol hace / cuando mirar este escuadrón le place», "Canción primera a la Armada Invencible», Poesias completas, II, vv. 72-75.

49. Tejada también recurre una sola vez a la imagen del león, pero es muy diferente: «del león vitorioso justa gloria», v. 94 .

50. Con probabilidad, Juan de Austria y Fernando el Católico (antes que Fernando I de Alemania; compárese con el cierre del soneto VI). Ignoro de qué Alfonso se trata. 
le convertirá en un «nuevo David», con lo que la oda acepta, como otras canciones heroicas, elementos bíblicos. El dominio de Felipe III se ejerce tanto en España -aunque aquí como acicate de un valor natural que Medrano no desarrolla («sienta España la espuela»)-, como fuera, entre los enemigos que hay que dominar («sienta el freno / quien desbocado no te sufre encima», vv. 61-62), y ambos dominios naturales están muy significativamente unidos por la imagen del caballo que monta y gobierna el rey, con espuela y freno, encima en los dos casos. La «diestra» real, con una espada, con una lanza, y con el bastón de mando vencerá a la multitud de enemigos. Es la misma «diestra» que aparece mencionada al comienzo blandiendo el «venablo vengativo" y el "cetro justo", según las ocasiones. También se vale, y es la primera vez que se menciona, de «la poderosa Armada» (v. 68). Se trata de vencer a los enemigos actuales, concretados en dos: «el galo e inglés molesto». Tejada desdobla en ocasiones al enemigo, en ingleses y turcos, aunque la canción se concentra en los primeros.

Frente a la cuidada ordenación de Tejada, cuya canción presenta una meditada presentación del poderío hispano antes de la batalla que resulta en la completa derrota de los enemigos, Medrano dedica la estancia VI a la descriptio de las fuerzas militares españolas, también conducida por el imperativo de rigor: «Del hispano atambor rimbombe el parche» (v. 71). La contaminación con los versos de Tejada es evidente, pero quiero insistir en la diferencia funcional: si en Tejada estos elementos aparecen en la cuarta estrofa y obedecen a un orden progresivo, en Medrano el aprovechamiento de los valores expresivos y significativos de Tejada carece de la misma coherencia dentro de su texto, cuya estructura, como indico más abajo, se ordena según otros principios no tan lineales como señala $\mathrm{D}$. Alonso. Los signos del «atambor» y la "trompa» proceden de Tejada, así como los términos "parche», «sonora», casi un mismo verso (el 29 de Tejada en el 81 de su composición), la referencia al «aire» o "viento vago» ${ }^{51}$. Retoma Medrano la mención de la Armada e insiste en los planes trazados por Tejada para el combate terrestre y marítimo en sólo dos versos: «tu Armada la salobre plata rompa, / mientras que por la tierra el campo marche» (vv. 74-75). Pero en VI se aprieta el resumen de la batalla y triunfo militar, con la "ayuda» de Tejada y se añade el pendón de Santiago (también en Tejada) y a Santiago mismo, para marcar esa inevitable fusión religioso-militar, convertido en un «Jove» opuesto a los «Joves mil valientes» del v. 37 y fundido en la imagen

51. En la canción de Góngora que precede a la de Tejada en las Flores se espigan referencias como «y al ronco son de trompas belicosas» (v. 3). La distancia sobre la primera canción cervantina es clara: «y aquel del atambor que engendra y cría / en el cobarde pecho valentía, I y el temor natural trueca y reforma», Poesías completas, II, vv. 69-71. 
bíblica de un diluvio («escupirá de rayos un diluvio», v. 83), lo que anticipa las referencias milagrosas, si hacen falta, de VII. Se cierra la estancia con el dúplice e insistente recuerdo del doble enemigo («contra el fiero britano y franco rubio", v. 84).

En la puntuación de Alonso-Reckert sólo hay dos estancias separadas menos tajantemente por la distancia que impone un punto y aparte, las VI y VII, pues el «que» con el que se abre VII parece pedir una continuidad sintáctica que se adecua a la unión de sentido de un desarrollo primero militar (con toques religiosos) que es luego religioso (con elementos militares). La importancia de ambos elementos queda reforzada por la extensión concedida en dos estrofas contiguas y enlazadas. Un nuevo paralelismo histórico o legendario es el que desarrolla VII con la mención de Teodosio y sus enemigos ${ }^{52}$ : el rey Felipe no es menos religioso y lo excepcional de la situación se marca en el papel de los enemigos cuya "perfidia» es mayor. Por eso se espera un combate con armas naturales habitualmente de difícil control e incluso alguna sobrenatural (ausentes de la canción de Tejada que se concentra en la maquinaria militar puramente humana) que libran su lucha por el rey: «militando por ti en escuadra fiera / la piedra, el huracán, la nube escura, / rayos, truenos, relámpagos, dragones, / y otras cien mil aéreas impresiones» (vv. 91-94). En esa constante predicción del futuro no muy concreto se sitúa el triunfo de la «fe pura», apuntalada por la imagen del vellocino ${ }^{53}$ y la referencia a Gedeón (otra vez la Biblia), para insistir en lo providencial y «milagroso» de esta victoria, para cuya consecución, si hiciera falta, se recurriría a la combativa intervención sobrenatural. Sí comparten, en esta parte final, la preocupación religiosa Tejada y Medrano, aunque el primero se ocupa por vía negativa de la herejía inglesa en dos estrofas, mientras Medrano acude a diversas referencias, bíblicas o no, para asegurar ese triunfo "con luces solas de fe pura».

Una vez obtenida la victoria, bendecida y asimilada a otros prestigiosos ejemplos, se canta el gozo del triunfo (VIII), con lo que la canción, en este aspecto, se vale de una circularidad (matizada por la intervención del

52. Teodosio I el Grande, emperador romano del siglo IV que se distinguió, entre otras cosas, por su lucha contra el arrianismo. Era de origen hispano (Diversas rimas, op. cit., p. 30).

53. Además de la alusión al Toisón de Oro («cuyo primado ostentaba el soberano», como anota Jesús Ponce), parece haber también un recuerdo de uno de los milagrosos episodios de la vida de Gedeón (Jueces 6: 36-40). Los capítulos 7 y 8 de Jueces relatan otros acontecimientos de la vida de Gedeón, entre ellos la victoria sobre los madianitas gracias a la estrategia de los cuernos y cántaros utilizados con sagacidad por trescientos hombres divididos estratégicamente. 
esquema organizativo de la fuerza-la paz-la fuerza-la paz que comento más abajo), pues este gozo remite al inicial, aunque ahora se abre con un futuro («verás risueño») de lo que son «agüeros tan felices». El triunfo afecta a tierra y mar y Medrano vuelve a Tejada para extractar lo esencial de la descriptio de la derrota (y no sólo a los versos que citan Alonso y Reckert, sino al esquema sintáctico que es tan plástico, pues Tejada abre su extensa presentación del triunfo militar con un «verás entonces» que es retomado por Medrano en su apertura de la estancia con un «verás risueño entonces»). Añade Medrano que las riquezas serán también para la iglesia («y de su gran despojo ornado el templo», v. 104), antes de exaltar la fama que adquirirá este joven rey, a quien como elogio máximo se le augura sin ninguna duda, triunfo y fama que se eternizan en las bellas artes (frente a la inmortalización que reserva Tejada a su pluma, de manera mucho más coherente con el papel de la poesía heroica).

El envío retoma la localización precisa de esta poesía de circunstancias (en el «Tormes») y supone una conclusión anticlimática, adecuada por la exaltación de la última estancia y acorde con el espíritu horaciano, quizá no tan ausente de esta oda como quería Dámaso Alonso ${ }^{54}$. En medio de un preciosismo colorista con el que se visten tópicamente los «cisnes» y «espumas» del Tormes, el poeta acaba con una autorreferencia que persigue el contraste entre la gloria del monarca y la humildad de autor y canción. Sin embargo, no deja de ser una finta retórica reservarse el último verso, la última palabra, que no por el freno del adjetivo oculta el orgullo de la autoría («humilde dueño») ${ }^{55}$.

Medrano organiza su texto a partir de una curiosa paradoja que procede del elemento circunstancial de la oda, pues se ve obligado a dar la bienvenida al monarca a la culta ciudad de Salamanca (elogiada en el v. 14, "tierra que huellas de tus pies merece»), y para ello propone un vestido y una actitud que representan bien la "pacífica toga» y la propuesta de que «manso escucha

54. Soledad Pérez-Abadín, en una visión más amplia, aunque divide las odas de Medrano en cuatro grupos («estrictamente morales», «amorosas», «heroicas», de "tema metaliterario»), encuentra conexiones: «A pesar de esta diversificación, todos los contenidos se elaboran sobre análogos supuestos éticos que sólo varían en la envoltura externa, ceñida al pretexto argumental del poema. De este modo, subyace a las cuatro modalidades temáticas un común planteamiento hedonista que da lugar a la exaltación del momento presente y al rechazo de las inquietudes que perturban el ánimo», «La oda en Francisco de la Torre...», p. 267.

55. Puede resultar útil recordar que a menudo en la poesía panegírica «el elogio del río supone uno indirecto del escritor»(G. Garrote Bernal, "La retórica de los Poemas Laudatorios...", p. 165), como indicio en este caso, pues Medrano no es el poeta alabado, y, aunque no hay en puridad un elogio del Tormes, su visión embellecida puede desempeñar una función similar. 
la lira». Pero, en los consejos que se dirigen a quien es aún joven, se vuelve sobre la fuerza que debe caracterizar a un rey (motivo que abre la oda inmediatamente detrás de la salutación) para que, a partir del ruido diverso que emiten «los atambores» de los enemigos (III), frente a la dulzura de la «lira» de bienvenida (I), el rey vuelva a rearmarse (V), en un movimiento de vaivén que se retoma al final del texto, vaivén que podría caracterizarse, desde el punto de vista funcional, como muy horaciano y que entraña cierta paradoja cuya superación se confía a la síntesis de un poder real en una ciudad dedicada al estudio.

Las innegables relaciones entre la canción de Tejada y la oda de Medrano se concentran en tres fragmentos de Tejada y cuatro de Medrano y es inmediatamente visible que más allá del aprovechamiento léxico no hay una similitud estructural (tal y como la diversa correspondencia en la numeración de los versos permitiría entrever). El aprovechamiento, más que anecdótico, se concentra en algunos motivos y lugares del poema, aunque no mantiene el orden expositivo ni, por supuesto, la función dentro del poema. Hay, además, otras relaciones entre ambos textos como la similitud, próxima a las ya apuntadas, entre el verso 16 de Tejada ( sii, despreciando el oro, ornare acero») y el 59 de Medrano ("descińa el oro y el acero oprima»), o entre los versos 131-132 de Tejada («y con espada y lanza / excedas la opinión de tu esperanza;») y los vv. 64-65 de Medrano ("contra cien mil estoques una espada, / tal una lanza oponga a cien mil dardos»). Otras posibles similitudes obedecen más bien al tópico general de la épica o de los elogios: «Tercero en nombre del que fue Segundo» (Tejada, v. 121) y "tu nombre (aunque tercero) sin segundo" (Medrano, v. 111); a esa tópica característica de un género responden los elogios y augurios positivos. La proximidad métrica (especialmente en la distribución de las rimas) ya fue notada por Dámaso Alonso, quien también situaba los dos poemas en torno a una cronología muy cercana, lo que hoy no es posible mantener, pues aunque aparentemente ambas canciones están motivadas por el mismo hecho, la subida al trono de Felipe III, Tejada reaprovecha su canción, compuesta hacia 1588, para la publicación en las Flores y la descircunstancializa (con los procedimientos y consecuencias que ha estudiado Lara Garrido). Por ello, sin duda, el contenido militar o épico de la canción de Tejada es mayor que el de la oda de Medrano, pues se orienta hacia el uso de la Armada en 1588 y canta un hecho militar que ocurrirá poco después (por más que la profecía de Tejada esté muy lejos de cumplirse). Medrano utiliza la primitiva canción de Tejada para componer un poema circunstancial que celebre la visita de Felipe III y su esposa a Salamanca. 
Las diferencias entre ambos poemas son mayores que sus puntos de contacto. Es muy perceptible la falta en Medrano de la asprezza de Tejada, y, en general, el cuidado del elemento sonoro es otro. El punto de partida es también distinto, pues Tejada parece hablar, en las Flores, de una futura e indeterminada victoria de las armas del rey sobre los ingleses (que, en las circunstancias de la composición primera, consistía en el triunfo de la llamada Armada Invencible sobre el "pirata inglés», v. 70), mientras la composición de Medrano nace para exaltar la figura del joven monarca en su visita a Salamanca en la primavera de 1600. De hecho, D. Alonso cree percibir, aunque no lo ha podido documentar, que el poema pertenece a un certamen: «El envío acredita que entró en concurso, o, por lo menos, que fueron escritas varias para la misma ocasión en Salamanca» ${ }^{56}$. La canción de Tejada se relaciona con textos de Herrera y Góngora (de hecho, el de éste le precede en las Flores), y la oda de Medrano, que naturalmente se relaciona con la canción de Tejada y con sus modelos, se conecta con otros textos propios escritos para la ocasión (un par de sonetos), con lo que el reparto de materiales poéticos e ideológicos debe tener en cuenta la necesidad del creador de llenar estos otros poemas circunstanciales que, a lo que parece, deben atender también, en un segundo reparto, a los dos destinatarios, los dos miembros de la realeza que visitan Salamanca: la reina Margarita y el rey Felipe III. Por ese origen distinto, los dos poemas trazan un retrato diferente de los enemigos del monarca, pues mientras Tejada se centra en el «gélido inglés» y en el "gran reino de Bretaña» (con alguna alusión al «soberbio turco", a quien la derrota inglesa servirá como aviso), Medrano anuncia una guerra triunfal «contra el fiero britano y franco rubio». Pero no sólo los intereses son distintos, sino también el aliento. Así en Tejada aparece un apóstrofe a Inglaterra (vv. 137-170, las dos estrofas anteriores al envío) con un rechazo explícito de su reina y con otras consideraciones (religiosas, Arturo como cuervo, etc.) que no tienen cabida en el poema panegírico de Medrano. También hay una neta e importante diferencia entre la profecía que se cierra con otra profecía ligada a la primera en la que se desarrolla la idea del acceso a la gloria por el poeta, que está en la apertura del texto de Tejada («y me promete palma y lauro nueuo,» v. 13) y en el cierre («que yo he de ser Virgilio de tal Marte», v. 175), frente a la buscada humildad de su final que Medrano parece oponer a su modelo («de altiva no presumas, / pasa entre las demás llana y sin ceño, / cual se precia de ser tu humilde dueño», vv. 118-

56. D. Alonso, op. cit., p. 232. Antes afirma que «está indudablemente escrita para ser leída en una sesión poética salmantina, entre otras poesías», p. 31. «El acto de "pasar entre las demás [canciones]» hace pensar en un contexto tan marcado como el de un certamen o justa poética», Diversas rimas, ed. Jesús Ponce Cárdenas, op. cit., p. 32. 
120), que ya he matizado antes. En Tejada se aprecia el empleo del motivo del sol para caracterizar a ambos rivales de manera opuesta, al tiempo que es un elemento más de cohesión en el poema, pues en la primera estancia el rey español mantiene complejas relaciones con Febo (que comento más arriba), mientras la falta de sol se recuerda tras la literaria derrota del inglés («pues que ves cuán soberbio se levanta / quien goza poco del hermoso Febo», vv. 124-125). El detalle, en general, recibe una atención especial en Tejada, frente a una construcción más discursiva en Medrano, por lo que no son infrecuentes las enumeraciones en Tejada, diseminativo-recolectivas (II), o que ocupan casi una estrofa (VII, que además de mostrar el dominio técnico y la riqueza semántica, refuerza funcionalmente el triunfo militar desarrollado con tanto detalle en la mención de los distintos elementos que conforman el equipo guerrero), o las descripciones (de la futura derrota naval del inglés -vv. 75-91- y de la celebración de la flota española -a continuación). Por último, Tejada mantiene a lo largo de toda la composición el pulso heroico, mientras Medrano entreteje elementos líricos, heroicos y panegíricos en su composición.

La oda ha sido valorada negativamente por Dámaso Alonso y, en alguna ocasión, aboga por excluirla de la valoración de las odas de Medrano precisamente por poseer ese insólito carácter circunstancial que la distancia de las demás odas ${ }^{57}$. Alonso recuerda que la oda fue elogiada por Gerardo Diego para, frente a Menéndez Pelayo, indicar que hay algo más que horacianismo en Medrano, aunque de inmediato Alonso reconduce el juicio hacia su visión: "Como ejemplo son buenos: nada menos horaciano. Pero digamos enseguida que esa oda, encargo de ocasión, es de lo más pegadizo en el arte de Medrano" ${ }^{58}$. Sin embargo, en este rechazo no sólo pesa lo que de frío e impostado encuentra en una composición tan unida a un motivo circunstancial (lo que, a su vez, se conecta con la frialdad y con la falta de grandeza del rey en cuestión, Felipe III), sino, de manera decisiva, la organización encadenada del discurso, la expresión lógica, frente a los saltos horacianos ${ }^{59}$. Por supuesto, también es un elemento esencial en la descalificación, tal y como se ha visto, lo que de «rimbombante» hay en la oda, que incluye una parte del vocabulario y el efecto sonoro de los pareados que cierran cada estancia, y cabría atribuir estas casi supuestas perversiones

57. D. Alonso, op. cit., p. 237; la incluye entre «obras periféricas», p. 136, n. 21.

58. D. Alonso, op. cit., p. 131.

59. «Esta oda IV es, en realidad, un frío discurso suasorio, y todas sus estrofas se encadenan lógicamente [...] Un frío orden razonador sustituye al auténtico balbuceo lírico», D. Alonso, op. cit., p. 235, n. 2. Creo que la idea habría que modificarla, o al menos matizarla, en varios de sus puntos. 
(si se comparan con la elogiada sencillez horaciana) a la influencia de Tejada. Por otro lado, y como muestra de que los «males» literarios en el caso de Medrano se relacionan con la ausencia de la benéfica influencia de Horacio, Alonso valora que en las tres odas no horacianas (IV, XVI y XXX) «es curiosa esta correspondencia: Medrano se aleja, en estas canciones, a la par de la forma y del contenido horacianos [...] Se ve, pues, que forma y contenido están indisolublemente ligados en su creación artística» ${ }^{60}$.

De hacer caso, pues, a Dámaso Alonso la elección de Tejada para tejer su oda de bienvenida a Felipe III habría sido negativa, pues de esa influencia procede el aspecto «rimbombante» del texto, frente al otro tono que caracteriza al mejor Medrano. Pero el aprovechamiento de la canción de Tejada no explicaría por sí solo la valoración negativa de la oda IV, pues otros elementos que contribuyen al rechazo hay que buscarlos en la presión de lo circunstancial (el desinterés de Medrano, la frialdad), en la propia falta de grandeza de la figura del rey (que nos ha transmitido la historia), en la falta de horacianismo (por más que Horacio también sea el conocido autor de una pieza de circunstancia para consagrar el mandato de Augusto ${ }^{61}$ ) que impide la humildad o la reflexión (sólo reconocidas en el commiato) y en la organización del poema de forma no discursiva o no lógica. Sin embargo esta postura supone la adopción de diversos axiomas y de algún error de planteamiento: axioma de la superioridad de lo horaciano sobre otros códigos; axioma de la inferioridad de las composiciones circunstanciales (menos evidente o menos formulado); en 1600, cuando presumiblemente se compone el poema, Felipe III tenía por delante unos veinte ańos para pasar a la historia como un monarca débil o poco grande, y Medrano, además, se suma a las obligadas bienvenidas literarias a la figura más alta del momento. Parecería interesante asumir que Medrano se vale de la imitación en dos de los textos sobre la entrada de Felipe III y su esposa, Margarita, en Salamanca, para la bienvenida obligada, y distinguir entre la oda y el soneto para la reina, de factura amorosa en el original por más que Medrano lo transforme, como quizá no podía ser de otro modo (un texto breve, además, que subraya la

60. D. Alonso, op. cit., p. 264, n. 1.

61. El Carmen saeculare, de 17 a. C. "Vingt-sept jeunes gens et vingt-sept jeunes filles, tous de famille noble, chantèrent l'hymne qu'Horace avait composé pour la circonstance [...] par la profondeur grave du sentiment patriotique c'est sans doute son chef-d'oeuvre dans la poésie religieuse», Horace, Odes et Épodes, texte établi et traduit par F. Villeneuve [1929], 10a ed., París, Belles Lettres, 1976, I, p. xl. «De modo que el poema entero, bajo la forma aparente de un himno a los dioses, pretende consagrar ante los ojos de todos la figura de Augusto como la del artífice de un tiempo nuevo", Horacio, Odas y Épodos, ed. bilingüe de Manuel Fernández-Galiano y Vicente Cristóbal, Madrid, Cátedra, 1990, pp. 376-377. 
importancia del rey, sobre la reina, dentro de esa exaltación necesaria de la monarquía a través de las artes, de la literatura en esta ocasión). Sin duda, visto el panorama desde hoy, hay un género, el elogio del monarca, que se corresponde con ciertos intereses políticos de propaganda y exaltación que se han estudiado más en el teatro. La "frialdad» ${ }^{62}$ quizá también sea una nota definitoria del género, por un lado, al tiempo que es una cuestión relativa que implica una comparación: ¿con la poesía íntima, o más íntima, con la amorosa, con la poesía que elige libremente -dentro de las posibilidades genéricas que brinda una época- el ánimo y las capacidades del poeta?

Si el paso del tiempo agosta cada vez más rápidamente la supuesta permanencia de los estudios filológicos (como ocurre en las demás disciplinas), el exceso de entusiasmo en la reivindicación de autores justa o injustamente olvidados o el apasionamiento en el análisis de los textos no parecen más que decisivas contribuciones a una pensada eternidad que no es más que la permanencia de lo momificado. Si es cierto que la mirada del investigador impregna el objeto de estudio de una subjetividad en la que afloran los prejuicios de una época, también es cierto que el ideal del presente (de cierto presente) pasaría por un acercamiento a los textos y por un desprendimiento de opiniones, axiomas y clichés para dejar que el texto hable (en la medida en que eso es posible, lo que no puede suponer nunca una suerte de grado cero del análisis). Por ello, más que valorar la oda de Medrano por su comparación con el resto de las odas que tan próximas se quieren de Horacio, el juicio sobre la oda IV debería manejar otros elementos: la comparación con la canción de Tejada de la que toma prestados versos e ideas, la adecuación al panegírico de circunstancias, la coherencia del contenido, la pertinencia de los recursos empleados para un determinado fin, etc.

Quedan diversas preguntas sin una contestación categórica, como ¿por qué eligió Medrano la canción de Tejada? Aunque no sabemos si se conocieron Tejada y Medrano, queda en pie la hipótesis de Lara Garrido que explica el "préstamo" por la diferencia de datación entre uno y otro poema, de manera que Medrano se acerca a un poema que parece haber perdido actualidad en 1600 para aprovechar la asprezza de Tejada en determinados momentos de su oda (en III, y más en la batalla [VI] y en el triunfo y derrota respectivos [VIII]). ¿Dónde leyó Medrano la canción de Tejada? Los dos testimonios más conocidos que la han conservado pueden ser posteriores a

62. Alonso contrapone la exaltación de la «imitación vivificadora» de Medrano a la «frialdad» de Herrera: «El arte de Medrano no es frío nunca: su temperamento de hombre pasa por el verso; éste estará imitado, pero una selección previa, por medio de la sensibilidad y la inteligencia, le ha llevado ya al ámbito del poeta: y por eso es sincero, tierno, dulcemente apasionado», F. de Medrano, Poesía, ed. D. Alonso, coord. M. L. Cerrón, pp. 81-82. 
la redacción de la oda. Sin embargo sí es posible responder otras cuestiones, como ¿qué es lo que Medrano aprovecha, como homenaje y como fina y fácil pedrería de su poema? Es significativo que Medrano combine elementos que proceden de estrofas diferentes de Tejada para componer las suyas (tal y como sucede en VI). Para dibujar las escenas bélicas de movimiento se vale de diecinueve versos de Tejada, pero evita, por ejemplo, la conocida acumulación de material militar de la estrofa VII de Tejada. También elude la directa apelación al joven Felipe III (VIII) para crear la suya (I y II) -excepto en la que parece tópica mención del oro y el acero- porque sus intereses son otros. Se vale, sin embargo, de pinceladas que proceden de II (la preparación bélica), con un valor muy simbólico, de IV (la batalla en su fragor) y V (la derrota). Parece que Medrano valora la fuerza de los versos de Tejada Páez que imita (compárense las estrofas $\mathrm{V}$-sin influencia de Tejada - y VI), aunque a veces la fuerza de Tejada es limada por el deseo de belleza de Medrano (como sucede con los vv. 35 y 36), quizá como parte del intento de imitar sin repetir, en la medida de lo posible (lo que explica las transformaciones de «reviente» en «rimbombe» $\mathrm{y}$ «movibles» en «portátiles») y para adaptarse a una enunciación distinta, en una oda (que forma serie con otros dos sonetos) destinada quizá a la lectura en voz alta en un certamen que celebra, no la inminente (y luego fracasada) invasión de la pérfida Albión, sino la visita del joven monarca Felipe III a la culta ciudad de Salamanca.

¿Apropiación u homenaje? Para tratarse de un homenaje quizá habría que introducir el elemento de la comunicación entre los poetas o del mutuo conocimiento, pues, si bien cabe un homenaje que no percibe el homenajeado (por ignorancia del texto), quizá, al tratarse de poetas de limitada resonancia (frente a otros casos) el homenaje deba pasar necesariamente por la aceptación, conocimiento o lectura del poema por el homenajeado, pues, de otra manera, parecería consistir en una apropiación que ¿quién iba a percibir? El límite, lábil en ocasiones entre uno y otra, parece más bien sugerir que Medrano opta por utilizar unos versos sonoros de Tejada para dar a su oda, en algunos pasajes, la fuerza de lo heroico, con independencia de la opinión de Tejada Páez o del quizá improbable reconocimiento del préstamo por otros poetas, apropiándose de una veintena de versos agrupados, preferentemente, en un par de estrofas, más allá de la habitual y aceptada imitación de temas o motivos. 


\section{BULLETIN HISPANIQUE}

Al Rey Don Felipe Nuestro Señor EL DOCTOR AGUSTÍN DE TEJADA

Tú, que en lo hondo del heroico pecho mides, con el cuidado congojoso, cuanto mide con luz el sol dorado, ya del indio de perlas abundoso y con ricos metales satisfecho,

ya del fiero alemán y hesperio osado, levanta el rostro de esplendor ornado y enhiesta la cerviz nunca domada, desde el Austro a las Ursas respetada; que colma con espíritus mis sienes de sus sagrados bienes el favorable Febo, y me promete palma y lauro nuevo, si me escuchas lo que él te profetiza; que es gloria que a los tuyos eterniza, si, despreciando el oro, ornare acero al ítalo, alemán y espańol fiero.

Mida el caballo con herradas manos lo que hay desde la cincha hasta el suelo, $y$ argente con espuma el freno duro, 20 y guarnezca el bruñido doble velo los pechos osadísimos hispanos, de la misma fiereza recio muro, y el mar, de tu potencia no seguro, horade el espolón, cercene y abra, con quien de crespa nieve el mar se labra; den a la luz del sol vistosas luces tus coloradas cruces,

y azote el viento vago

el vencedor pendón de Santïago; y relumbren al sol yelmos grabados por entre los penachos encrespados, porque ya del inglés pide venganza yelmo, peto, caballo, espada y lanza.

Pues en tu gente invicta y laureada la virtud su virtud acendra y prueba, bata Milán el duro yunque, bata, grabe los yelmos, temple bien la greba, enaste hierros y acicale espada, que en sangre tińa su color de plata, y en fragua, do la llama se desata, con los roncos martillos armas forje contra el reino que un tiempo honró [a san Jorge;

y con la belicosa barahúnda

se amedrente y confunda,

y el español supremo

contra el gélido inglés muestre su extremo; y el atanor de bronce, por do pasa, no el agua dulce mas sulfúrea brasa, escupa con relámpagos horrendos, rayos de plomo y truenos estupendos.
ODE IV

FRANCISCO DE MEDRANO

Ilustre joven, cuya rubia frente en edad tan dichosa el oro cińe, cuya diestra ya rige el cetro justo, ya del venablo vengativo tińe los aceros en púrpura caliente del fiero jabalí, del oso adusto, entra gozoso, cual tu padre augusto, en pacífica toga; alegre mira de la ciudad vistosa el rico adorno; la turba que te adora y cińe en torno 10 cuál pasma, cuál te aclama, cuál se

[admira;

manso escucha la lira;

goza en julio del mayo que te ofrece tierra que huellas de tus pies merece.

Y si bien la florida adolescencia, adulta apenas, tus mejillas cubre y esparce en ellas sus primeras flores, si aún están lejos del lluvioso octubre los frutos que madura la experiencia, pues los da el seso y el valor mejores, entre estos gustos que, cual ruiseñores, las memorias aduermen cuidadosas, prudente advierte, oh sin igual monarca, que cuanto el uno y otro mundo abarca, cuanto atalayan de ellos las dos Osas 25 que el mar huyen medrosas, tanto en este sustentas y aquel hombro, siendo a la tierra envidia, al cielo [asombro.

Aplica, señor, pues, sabio el oído, y en él retiñirán los atambores del fementido galo e inglés pirata; la vista tiende próvido y de flores mira el aire sutil enriquecido, que las despliega blando y las dilata; mira en el golfo de crespada plata mil portátiles torres fabricadas y en la campańa Joves mil valientes escupiendo de sí rayos ardientes, cuerpos de acero y almas de ira armadas, con la muerte aliadas en una voz y en un conforme hipo de escurecer el nombre de Filipo.

Alienta, alienta tu nativo instinto, generoso león, y con la cola que atrás de mil hazañas vas dejando, azora tu coraje, pues no es sola la sangre de un invicto Carlos Quinto, de un Juan o de un Alfonso o de un

[Fernando 
ENTRE LA APROPIACIÓN Y EL HOMENAJE: TEJADA PÁEZ Y MEDRANO

$\mathrm{Al}$ atambor se le reviente el parche, y el cañón a la trompa le reviente $\mathrm{y}$ al aire atruene su sonoro aliento; y adonde el pie de tu soldado asiente cuando tu vitorioso campo marche, con la sangre enemiga esté sangriento. Cuando puebles el húmido elemento y con movibles casas abras surco al inglés rojo y al soberbio turco, tus coronadas popas y tus gavias, llenas de gentes sabias, de despojos tan llenas vendrán, que los que están en las cadenas no podrán con el remo abrir camino; mas para proseguir tan buen destino, al duro banco el brazo hereje amarra, para que el mar con remos are y barra.

Pero ten cuenta, cuando ya la lanza contra el pirata inglés bravo enarboles, 70 y el nervio estires del corvado arco, que la salobre plata la arreboles con su herética sangre por venganza, y des rojo color al blanco charco. Su nao mayor tu más pequeño barco ajorro arrastrará, y aun sus banderas besarán de la mar las aguas fieras; veranse en sus navíos abrasados los arcos destrozados, y sus botas espadas sin gloria por el suelo derribadas; ricas aljabas y saetas fuertes en propio dańo suyo y propias muertes; sus galeras quemadas, sus naos rotas, urcas, barcas, esquifes, galeotas.

El mar, envuelto con arenas hondas, con los cuerpos que nadan, no nadando por estar de la vida despojados, como con azanefas adornando su orilla, irá con ellos, y con ondas de los rojos esmaltes ya cuajados. Veranse por tus mástiles alzados ricos trofeos de inmortal memoria, del león vitorioso justa gloria; y al cielo perlas líquidas veremos que arrojarán tus remos por mensajeros ciertos de las vitorias que honrarán tus puertos, con que se turbarán esos turbantes de los bárbaros fieros arrogantes, sin que le valga al scita y masageta el cielo barrenar con la saeta.

Verás entonces a tus pies rendidos golas petos, montantes y celadas, arcos, ballestas, dardos, tablachinas, dagas, estoques, picas con espadas,

la que en tus venas arma está tocando, mas la de una Isabel y otras mujeres que a sus pies derribaron con la rueca el orgullo del ídolo de Meca y con sus fuerzas Galia y sus haberes temió sus alfileres, del capitán francés glorioso ultraje y gloria eterna de tu real linaje.

Ponga ya al malo horror, dé audacia al

ver que tu justa indignación se atufa; descińa el oro y el acero oprima, nuevo David, esa melena rufa; sienta España la espuela y sienta el freno quien desbocado no te sufre encima; y esa diestra, señor, tal vez esgrima contra cien mil estoques una espada, tal una lanza oponga a cien mil dardos 6 y tal vez de tus jóvenes gallardos con el bastón gobierne, respetada, la poderosa Armada, hasta que el galo e inglés molesto rindan al yugo tuyo el cuello enhiesto.

Del hispano atambor rimbombe el parche, $\mathrm{y}$ al aire asorde tu sonora trompa, el acero luciente al sol deslumbre, tu Armada la salobre plata rompa, mientras que por la tierra el campo

vitorioso, cual tiene de costumbre; suspire en afrentosa servidumbre el pueblo que en desprecio del halago su castigo imprudente solicita; con muda lengua adore y faz marchita 80 al vencedor pendón de Santïago, que desde el aire vago escupirá de rayos un diluvio contra el fiero britano y franco rubio.

Que pues ni en fe, ni en religión, ni en [celo 85

era mayor Teodosio y la perfidia de tus émulos lleva delantera a los suyos, malgrado de la envidia, espera venturoso ver al cielo conducido, seńor, a tu bandera, militando por ti en escuadra fiera la piedra, el huracán, la nube escura, rayos, truenos, relámpagos, dragones y otras cien mil aéreas impresiones; si ya con luces solas de fe pura, pues la insignia en ti dura del Vellocino, cual Gedeón celoso, vencedor no salieses milagroso.

Verás risueño entonces sus banderas, 


\section{BULLETIN HISPANIQUE}

manoplas, brazaletes y lucidos yelmos, rodelas, cotas, culebrinas, alfanjes duros, mallas jacerinas, truenos, pasavolantes y bombardas, jinetas, partesanas y alabardas, los versos, basiliscos y mosquetes, bombas y morteretes, venablos y gorguces, trabucos, roncas, grebas, arcabuces, las balas, escopetas y corazas, hierros, sillas, testeras, frenos, mazas $y$, al fin, de todo, sus cervices duras sujetas a tus lazos y ataduras.

Y tú, pimpollo tierno y tierna planta, Tercero en nombre del que fue Segundo, del tronco de Austria singular renuevo, aumenta con tu edad el bien al mundo, pues que ves cuán soberbio se levanta quien goza poco del hermoso Febo. Prometes nueva gloria y siglo nuevo, y pues el brío juvenil apenas se ha divertido por tus reales venas, abrevia el tiempo que de acero claro cubras el cuerpo raro, y con espada y lanza excedas la opinión de tu esperanza; y pues que de la nuestra eres coluna, no temas hado, tiempo ni fortuna, que a tu querer, del mundo respetado, 135 responderán fortuna, tiempo y hado.

Y en tanto, ¡oh tú, gran reino de Bretaña!, de armas un tiempo singular trofeo, sacude aquesa infamia que te infama; adorna tu blasón con el deseo con que te quiere honrar la invicta Espańa, pues ves que a voces te apellida y llama, antes que encienda su corusca llama tus muros, capiteles y molduras, y las torres, del tiempo no seguras.

¿Por qué sujetas tu feroz braveza

a mujeril vileza,

y tu gran valentía

a cabeza de seso tan vacía?

Pues la regia corona y la diadema, por verse puesta en frente tal, blasfema, por ser más digna tan lasciva frente que el rizo de oro encrespe el fuego

[ardiente.

Si esperas a tu Arturo hecho cuervo, lleno de glorias y de triunfos lleno, ¿por qué de ti no arrojas esa graja antes que cunda más su cruel veneno? Hija proterva de varón protervo, que el poder que dio a Pedro Cristo ataja. Aunque en esto su gloria se aventaja, pues han poblado por su hereje celo prospere el cielo agüeros tan felices, besar la tierra humildes para ejemplo, arrastradas sus naves infelices a jorro por tus ágiles galeras y de su gran despojo ornado el templo. Mil tablas luego y piedras mil [contemplo,

eternizados tus trofeos en ellas, por pompa de este siglo y para envidia del pincel y buril de Zeuxi y Fidia, y subir de ti asida a las estrellas la Fama y colgar de ellas

tu nombre (aunque tercero) sin segundo, para favor y emulación del mundo.

Canción, si hallas lugar entre los cisnes que el Tormes rompen y entre sus

[espumas,

-vueltos, para mejor pulirse, en ojospies ostentan y picos de oro rojos, y de cándida plata blancas plumas, de altiva no presumas, pasa entre las demás llana y sin ceńo, cual se precia de ser tu humilde dueño. 120

Soneto VII

Borde Tormes de perlas sus orillas sobre las yerbas de esmeralda y Flora hurte para adornarlas al'Aurora las rosas que arrebolan sus mejillas;

viertan las turquesadas maravillas y junquillos dorados, que atesora la rica gruta donde el viejo mora, sus dríades en cándidas cestillas,

para que pise Margarita ufana, llenando tierra y agua de favores. Mas si uno y otro mira con desvío,

ni las ninfas de Tormes viertan flores, ni rosas hurte Flora a la mańana, ni su orilla de perlas borde el río. 


\section{ENTRE LA APROPIACIÓN Y EL HOMENAJE: TEJADA PÁEZ Y MEDRANO}

cuerpos las horcas, ánimas el cielo, enrubiando de mártir sangre santa que al cielo se levanta,

tus yerbas y tus flores, que dieron otro tiempo mil olores de holocaustos, de víctimas y ofrendas, para el Dios de Israel queridas prendas; y agora sólo dan horror eterno, triste prodigio del horrendo infierno.

Canción detén el vuelo;

que mayor lauro te promete el cielo cuando, alcanzada la britana gloria, oídos preste el mundo al verso culto; que yo he de ser Virgilio de tal Marte, que esparza el nombre suyo y mi memoria desde Pirene hasta aquella parte que inflama el fuego del Canopo oculto, y desde el oceano,

hasta el mar que con yelos está cano.

Pedro Espinosa, Flores de poetas ilustres, ed. Belén Molina Huete, Sevilla, Fundación José Manuel Lara, 2005, pp. 59-67.

\section{Soneto VIII}

Soberano Seńor, cuyo semblante tal vez nos representa a Marte crudo, con el estoque vengador desnudo y la túnica estrecha de diamante;

tal, nos pone pacífico delante, preso el cabello con vistoso ńudo de lauro y con un libro por escudo, no menos sabio a Apolo que elegante,

honra ahora las letras y con ellas, émulo de tu padre y de sus leyes, da a la paz el dominio de tu tierra;

de tu abuelo, después, sigue las huellas, pues igualmente es propio de los reyes amar la paz y ejercitar la guerra.

Francisco de Medrano, Diversas rimas, ed. Jesús Ponce Cárdenas, Sevilla, Fundación José Manuel Lara, 2005, pp. 24-33. 